\title{
Pemanfaatan Sumber Belajar Non Teks di Sekolah Dasar Wilayah Kecamatan Wringinanom Kabupaten Gresik
}

\author{
I Wayan Arsana ${ }^{1}$, Hartono², Dyah Ayu Anggraini ${ }^{3)}$ \\ Email $^{1}$ : arsana.wayan@unipasby.ac.id \\ Email² : hartono@unipasby.ac.id \\ Email $^{3}$ : dyahayuanggraini58@gmail.com
}

Fakultas Ilmu Sosial dan Humaniora, Universitas PGRI Adi Buaan Surabaya

Abstrak

Penelitian ini termasuk jenis penelitian deskriptif yaitu penelitan yang dilakukan pada objek alamiah yaitu objek yang berkembang secara apa adanya. Penelitian ini mendeskripsikan mengenai pemanfaatan sumber belajar non teks. Hasil dari peneltian ini yaitu: 1) Sebagian besar pemanfaatan sumber belajar non teks di sekolah sudah memadai tetapi ada beberapa sumber belajar non teks yang belum tersedia seperti laboratorium, ruangan komputer 2) Sebagian besar jenis sumber belajar non teks yang paling sering digunakan dalam proses pembelajaran yaitu peta dan buku teks 3) Sebagian besar tidak ada kendala yang terkait dengan ketersedian sumber belajar non teks, kemapuan atau keterampilan guru dalam menggunakan sumber belajar dan kondisi sosial yang mempengaruhi pemanfaatan sumber belajar 4) Upaya dalam mengatasi kendala-kendala dalam pemanfaatan sumber belajar non teks di sebagian sekolah sudah memadai dan ketersedian sumber belajar yang belum tersedia biasa guru menggunakan alat seadanya 5) Sebagian besar menyatakan pemanfaatan sumber belajar non teks di sekolah sudah dimanfaatkan dengan baik oleh guru dan disesuaikan dengan tema-tema pembelajaran 6) Sebagian besar sekolah menyatakan melakukan perawatan secara berkala agar sumber belajar terawat dengan baik 7) Sebagian besar sekolah menyatakan bahwa pengadaan sumber belajar non teks di sekolah dilakukan dengan baik dan berkoordinasi dengan kepala sekolah dan staf TU 8) Semua guru menyatakan pendapatnya tentang pemanfaatan sumber belajar non teks di sekolah sangat bermanfaat bagi guru dalam proses pembelajaran yang dilakukan oleh guru agar peserta didik tidak bosan dan peserta didik lebih cepat memahami pelajaran yang diberikan guru.

Kata kunci: sumber belajar, non teks

Abstract

This research is a descriptive type of research, namely research conducted on natural objects, namely objects that develop as they are. This study describes the use of non-text learning resources by grade $V$ students in elementary schools. The results of this research are: 1) Most of the use of non-text learning resources in schools is adequate but there are some non-text learning resources that are not yet available such as laboratories, computer rooms 2) Most types of non-text learning resources are most often used in the learning process Namely maps and textbooks 3) Mostly there are no limitations related to the availability of non-text learning resources, the ability or skills of teachers to use learning resources and social conditions that affect the use of learning resources 4) Efforts to overcome problems in the use of non-learning resources The text in some schools is adequate and the availability of learning resources is not yet available. It is normal for teachers to use makeshift tools 5) Most of the designated use of non-text learning resources in schools have been used properly by teachers and are adjusted to learning themes 6) Most of the schools used carry out treatment in style so that learning resources are well maintained 7) Most of the texts that state that the provision of learning resources in schools is carried out properly and in coordination with the principal and administrative staff 8) All teachers who express their opinion about the use of non-text learning resources in schools are very useful for teachers. the learning process carried out by the teacher so that students do not get bored and learners understand the lessons given by the teacher more quickly. 


\section{PENDAHULUAN}

Proses pembelajaran di sekolah merupakan satu kegiatan yang paling pokok dan mendasar dalam proses pendidikan. Pembelajaran adalah merupakan aktivitas yang berlangsung di dalam atau di luar kelas, melalui proses memungkinkan pebelajar mengembangkan bakat, minat dan kemampuannya secara optimal. Sedangkan keberadaan pembelajar merupakan komponen penting dari proses pembelajaran karena keberhasilan proses pembelajaran tergantung pada kemampuan pembelajar dalam menguasi materi, memilih strategi maupun sumber belajar yang ada. Sering kali pembelajar dalam proses pembelajarannya mengalami kesulitan sehingga proses pembelajaran menjai monoton, tidak menarik dan cenderung membosankan.

Disisi lain keberadaan sumber belajar memiliki posisi yang sangat penting dan strategis, dalam kontek ini sumber merupakan segala sesuatu yang dapat dimanfaatkan untuk mendukang proses pembelajaran di kelas maupun di luar kelas baik secara langsung maupun tidak langsung. Kadir (2019) menjelaskan sumber belajar adalah segala sesuatu yang bisa di manfaatkan guna kepentingan proses pembelajaran secara keseluruhan. Merujuk dari paparan di atas sumber belajar adalah segala sesuatu untuk mendukung keberhasilan proses pembelajaran di kelas sehingga pebelajar dapat mencapai suatu kompetansi tertentu yang telah ditetapkan sebelumnya. Sedangkan AECT (Assocition for Educational Communication and Technologi) mengelompokan komponen sumber belajar dalam kawasan teknologi pendidikan yang terdiri , pesan, orang, bahan, alat, prosedur dan lingkungan. Musfiqon (2015:128) sumber belajar yang digunakan sebagai sumber informasi, sumber alat, sumber peraga, serta kebutuhan lain dalam proses pembelajaran.
Keberadaan sumber velajar disekolah sangat dibutuhkan karena pemanfaatan sumber belajar akan membantu pembelajar dalam memperbaiki dan mengikatkan kualitas belajarnya, artinya keberadaan sumber belajar sangat membantu pebelajar dalam memahami materi pembelajaran yang akan dipelajari. Berdasarkan pengamatan secara terbatas masih di temui pembelajar maupun pebelajar belum memanfaatkan sumber belajar secara optimal dalam proses belajarnya, kondisi demikian akan mengakibatkan pebelajar menjadi bosan dan kurang berminat, dalam mengikuti pembelajaran. Selama ini pembelajar cendrung menggunakan sumber belajar teks sebagai satu-satunya sumber belajar akibatnya pembelajaran lebih banyak berlangsung dengan pendekatan konvensional. Disamping kurangnya kemampuan pembelajar dalam memilih dan menggunakan sumber belajar, masih ada permasalahan lain yang dihadapi oleh pembelajar serta ketersediaannya yang masih sangat terbatas. Padahal keberadaan sumber belajar disekitar kehidupan pebelajar yang beraneka ragam yang bersifat (by design) maupun yang bersifat sengaja dibuat (by utilization) belum jika dilihat dari ketersediaannya lebih banyak sumber belajar teks bila dibandingkan dengan sumber belajar non teks.

Sejalan dengan perkembangan teknologi informasi, pembelajar diharapkan mampu memilih dan menggunakan sumber belajar yang bervariasi, segala potensipotensi yang tersebar di sekolah dan dimasyrakat harus dapat dimanfaatkan oleh pembelajar sehingga berdaya guna positif untuk mencapai keberhasilan belajar bagi pebelajar. Berdasarkan temuan tersebut masih banyak pebelajar yang belum memanfaatkan sumber belajar secara optimal disekolah dasar. Mejuruk pada paparan di atas pebelajar disekolah dasar perlu diberikan perhatian yang lebih sungguh-sungguh terutama mengenai 
pemanfaatan sumber belajar non teks yang bervariasi mampu menambah minat dan semangat belajar bagi pebelajar.

\section{METODE PENELITIAN}

Penelitian ini termasuk jenis penelitian deskriptif yaitu penelitan yang dilakukan pada objek alamiah yaitu objek yang berkembang secara apa adanya. Nazir (2005:89) penelitian deskriptif adalah studi untuk menemukan fakta dengan interpretasi yang tepat. Sedangkan Kountor (2009) penelitian deskriptif adalah penelitian yang memberikan gambaran atau uraian susatu keadaan sejelas mungkin tanpa ada perlakuan terhadap objek yang diteliti. Penelitian ini mendeskripsikan mengenai pemanfaatan sumber belajar non teks ooeleh pebelajar kelas V di Sekolah Dasar wilayah Kecamatan Wringinanom Kabupaten Gresik.

Data yang akan digunakan dalam penelitian ini adalah data yang diperoleh fakta fakta yang diperoleh dari responden melalui angket. Dalam konteks penelitian ini meliputi data mengenai pemanfaatan sumber belajar non teks di Sekolah Dasar wilayah Kecamatan Wringinanom Kabupaten Gresik mengenai pemanfaatan sumber belajar non teks pebelajar kelas V di Sekolah Dasar wilayah Kecamatan Wringinanom Kabupaten Gresik. Sumber data dalam penelitian ini terdiri dari 2 jenis sumber data yakni pembelajar kelas $\mathrm{V}$ dan pebelajar kelas V di Sekolah Dasar wilayah Kecamatan Wringinanom Kabupaten Gresik. Subyek Penelitian ini adalah pebelajar kelas V Sekolah Dasar yang tersebar wilayah Kecamatan Wringinanom Kabupaten Gresik. Banyaknya Subyek Penelitian ini ditentukan antara 10-20 $\%$.).

Hal ini sesuai dengan pendapat Arikunto yang menyatakan dalam penelitian deskriptif besar sampel antara 10-20\%.) seluruh subyek. Dengan ditentukannya subyek penelitia antara 10 $-20 \%$ Hal ini dilakukan agar temuan penelitian ini dapat digeneralisasikan. Adapun teknik penentuan subyek dilakukan dengan cara random sampling cara undian.
Teknik pengumpulan data adalah cara yang digunakan dalam penelitian untuk menggali dan memperoleh informasi mengenai pemanfaatan sumber belajar non teks oleh pebelajar kelas $\mathrm{V}$ sekolah dasar, ada dua instrument yang digunakan dalam proses pengumpulan data yakni angket dan dokumentasi.

Teknik analisis data adalah proses kategori urutan data mengorganisasikan ke dalam suatu pola, kategori dalam suatu uraian dasar, yang membedakannya dengan penafsiran yaitu memberikan arti yang signifikan terhadap analisis, menjelaskan pola uraian dan mencari hubungan diantara dimensi-dimensi uraian. Dalam penelitian ini teknik analisis data menggunakan teknik analisis statistik deskriptif.

\section{HASIL DAN PEMBAHASAN}

Berdasarkan hasil penemuan data penelitian yang telah di paparkan di atas maka sebagai gambaran tentang pemanfaatan sumber belajar non teks di kelas V Sekolah Dasar di wilayah Kecamatan Wringinanom Kabupaten Gresik, dapat dideskripsikan sebagai berikut:

1. Ketersedian sumber belajar non teks di kelas V Sekolah Dasar di wilayah Kecamatan Wringinanom Kabupaten Gresik.

Berdasarkan hasil analisis tentang ketersedian sumber belajar non teks yang sering di gunakan oleh 56 orang pembelajar, menunjukan sebanyak 47 orang pembelajar atau sebesar $84 \%$ menyatakan bahwa ketersedian sumber belajar non teks yang ada di kelas V Sekolah Dasar di wilayah Kecamatan Wringinanom Kabupaten Gresik memadai, 7 orang pembelajar atau sebesar $12,5 \%$ menyatakan bahwa ketersedian sumber belajar non teks yang ada di kelas V Sekolah Dasar di wilayah Kecamatan Wringinanom Kabupaten Gresik kurang memadai. Begitu juga dengan hasil analisis kelengkapan sumber belajar non teks di kelas V Sekolah Dasar di wilayah Kecamatan Wringinanom Kabupaten Gresik yang di berikan kepada 56 orang pembelajar , menunjukan bahwa 46 orang pembelajar 
atau sebesar 82,1\% menyakatan sumber belajar non teks yang ada di kelas V Sekolah Dasar di wilayah Kecamatan Wringinanom Kabupaten Gresik lengkap, 10 orang pembelajar atau sebesar 17,9\% menyataka sumber belajar non teks yang ada di kelas $\mathrm{V}$ Sekolah Dasar di wilayah Kecamatan Wringinanom Kabupaten Gresik tidak lengkap.

Data yang di peroleh ini didukung oleh hasil dokumentasi pada 7 sekolah dan seluruh narasumber yaitu para pembelajar dari kelas rendah ke kelas tinggi menyatakan bahwa sumber balajar non teks yang tersedia dan kelengkapan di masing-masing Sekolah Dasar sudah memadai. Ketersedian dan kelengkapan sumber belajar non teks sebagian besar sudah disediakan oleh pihak sekolah. Sumber belajar tidak terbatas pada buku teks saja. Sumber belajar banyak beragam seperti sumber belajar non teks yang bisa dibuat oleh pembelajar sesuai dengan tema yang akan di ajarkan pada pebelajar .

2. Kendala-kendala yang di hadapi oleh pembelajar di Sekolah Dasar dalam pemanfaatan sumber belajar non teks di kelas V Sekolah Dasar di wilayah Kecamatan Wringinanom Kabupaten Gresik.

Tidak ada kendala yang berarti dalam pemanfaatan sumber belajar non teks yang ada di sekolah tersebut sudah di sediakan oleh sekolah dan ada beberapa sumber belajar non teks yang tidak ada karena terbatas oleh dana dan tempat yang ada di kelas V Sekolah Dasar di wilayah Kecamatan Wringinanom Kabupaten Gresik. Berdasarkan hasil analisis tentang kendala-kendala yang di hadapi oleh pembelajar dalam pemanfaatan sumber belajar non teks yang ada di kelas V Sekolah Dasar di wilayah Kecamatan Wringinanom Kabupaten Gresik, dalam pembelajaran melalui 56 pembelajar yang menunjukan 26 pembelajar dengan persentase $46,4 \%$ menyatakan bahwa ada kendala yang di hadapi oleh pembelajar dalam proses pembelajaran dikelas, 30 pembelajar dengan persentase $53,6 \%$ menyatakan bahwa tidak ada kendala dalam proses pembelajaran di kelas. Begitu juga dengan hasil analisis tentang jenis kendala yang di hadapi pembelajar dalam pemanfaatan sumber belajar non teks di kelas V Sekolah Dasar di wilayah Kecamatan Wringinanom Kabupaten Gresik yang di berikan kepada 56 pembelajar yang menunjukan 22 pembelajar dengan persentase 39,2\% menyatakan bahwa alat tidak tersedia, 33 dengan persentase $58,9 \%$ bahwa pedoman penggunaan tidak tersedia. Berkaitan dengan kondisi sosial juga tidak ada kendala, tetapi ada kendala-kendala kecil yang berkaitan dengan teknis yang berupa jaringan internet yang kadang-kadang mengunakan hospot dari hp pembelajar dikarenakan jaringan wifi macet atau tidak setabil, laboarotium dan ruangan komputer yang belum tersedia karena kendala dari kekurangan lahan yang ada di sekolah.

3. Cara mengatasi kendala dalam pemanfaatan sumber belajar non teks di sekolah.

Berdasarkan hasil analisis tentang cara mengatasi kendala-kendala oleh pembelajar dalam pemanfaatan sumber belajar non teks yang ada di kelas V Sekolah Dasar di wilayah Kecamatan Wringinanom Kabupaten Gresik, dalam pembelajaran melalui 56 orang pembelajar yang menunjukan 34 orang pembelajar atau sebesar $60,7 \%$ menyatakan bahwa pembelajar melakukan koordinasi dengan kepala sekolah, 19 orang pembelajar atau sebesar $34 \%$ menyatakan bahwa melakukan koordinasi dengan pembelajar .

Merujuk pada angket tersebut bisa dilihat dan disimpulkan bahwa pembelajar di kelas V Sekolah Dasar di wilayah Kecamatan Wringinanom Kabupaten Gresik lebih banyak melakukan koordinasi dengan kepala sekolah untuk mengatasi kendala-kendala dalam pemanfaatan sumber belajar non teks yang ada di kelas V Sekolah Dasar di wilayah Kecamatan Wringinanom Kabupaten Gresik. Hal ini di karenakan oleh berapa alasan yaitu: koordinasi dengan kepala sekolah lebih bisa mengatasi kendala yang yang ada di kelas mau pun di sekolahan.

4. Pemanfaatan sumber belajar non teks di kelas $\mathrm{V}$ Sekolah Dasar di wilayah Kecamatan Wringinanom Kabupaten Gresik 
Pemanfaatan sumber belajar dengan segala bentuk dukungan yang diberikan dari berbagai pihak yaitu sekolah dan orang tua dalam upaya pemanfaatan sumber belajar bisa terealisai dengan baik. Dukungan dari berbagai pihak dapat membantu dan memudahkan para pembelajar di kelas V Sekolah Dasar di wilayah Kecamatan Wringinanom Kabupaten Gresik, untuk lebih memanfaatkan sumber belajar non teks dengan baik.

Berdasarkan hasil analisis tentang pemanfaatan sumber belajar non teks yang ada di kelas V Sekolah Dasar di wilayah Kecamatan Wringinanom Kabupaten Gresik, dalam pembelajaran melalui 56 orang pembelajar yang 10 orang pembelajar atau sebesar $17,9 \%$ menyatakan bahwa pembelajar sudah memanfaatkan dengan tema tertentu yang terkait dengan pengunaan sumber belajar non teks, sedangkan 24 orang pembelajar atau sebesar $42,8 \%$ menyatakan bahwa kurang maksimal karena terbatas pedoman penggunan dalam pemanfaatan sumber belajar non teks.

5. Pendapat pembelajar tentang penggunaan sumber belajar non teks yang ada di sekolah.

Kemampuan atau keterampilan pembelajar menggunakan sumber belajar non teks sangat penting untuk diketahui, kemampuan atau keterampilan pembelajar merupakan cara pembelajar untuk mengelola dan menggunakan sumber belajar non teks secara baik dan benar. Untuk itu peneliti perlu mengetahui pendapat pembelajar mengenai kemapuan atau keterampilan dalam mengunakan sumber belajar yang ada di sekolah. Berdasarkan hasil analisis tentang cara pengunaan sumber belajar oleh pembelajar pada saat proses pembelajaran di kelas yang di berikan kepada 56 pembelajar menunjukan sebanyak 19 pembelajar dengan persentase $33,9 \%$ menyatakan bahwa pendapat pembelajar tentang perawatan sumber belajar non teks dilakukan oleh pembelajar dan TU yang ada di sekolah, 21 pembelajar dengan persentase $37,5 \%$ menyatakan bahwa pendapaat pembelajar perawatan sumber belajar non teks cukup terawat dengan baik.

\section{KESIMPULAN}

Setelah dilakukan penelitian maka peneliti menemukan data penelitian dan pembahasan yang mengulas tentang penelitian yang berupa kesimpulan sebagai berikut.

1. Sebagian besar pemanfaatan sumber belajar non teks di sekolah sudah memadai tetapi ada beberapa sumber belajar non teks yang belum tersedia seperti laboratorium, ruangan komputer.

2. Sebagian besar jenis sumber belajar non teks yang paling sering digunakan dalam proses pembelajaran yaitu peta dan buku teks. Ada beberapa guru yang menggunkan sumber belajar non teks di luar kelas agar peserta didik tidak bosan.

3. Sebagian besar tidak ada kendala yang terkait dengan ketersedian sumber belajar non teks, kemapuan atau keterampilan guru dalam menggunakan sumber belajar dan kondisi sosial yang mempengaruhi pemanfaatan sumber belajar.

4. Upaya dalam mengatasi kendala-kendala dalam pemanfaatan sumber belajar non teks di sebagian sekolah sudah memadai dan ketersedian sumber belajar yang belum tersedia biasa guru menggunakan alat seadanya. Guru juga melakukan koordinasi dengan kepala sekolah.

5. Sebagian besar menyatakan pemanfaatan sumber belajar non teks di sekolah sudah dimanfaatkan dengan baik oleh guru dan disesuaikan dengan tema-tema pembelajaran.

6. Sebagian besar sekolah menyatakan melakukan perawatan secara berkala agar sumber belajar terawat dengan baik.

7. Sebagian besar sekolah menyatakan bahwa pengadaan sumber belajar non teks di sekolah dilakukan dengan baik dan berkoordinasi dengan kepala sekolah dan staf TU.

8. Semua guru menyatakan pendapatnya tentang pemanfaatan sumber belajar non teks di sekolah sangat bermanfaat bagi guru dalam proses pembelajaran yang dilakukan oleh guru agar peserta didik tidak bosan dan peserta didik lebih cepat memahami pelajaran yang diberikan guru

\section{REFERENSI}

Arikunto, S.2015.Prosedur Penelitian: Suatu Pendekatan Praktik. Jakarta: Rineka Cipta.

http://jurnalonline.um.ac.id/_ pemanfaatan sumber belajar dalam proses pembelajaran pendidikan 
kewargabegaraan. Diunduh pada 09 september 2019 pukul 21.14

http://jurnal.unswagati.ac.id/ pengaruh pengunaan buku teks pelajaran dan internet sumber belajar terhadap hasil belajar siswa pada pembelajaran IPS. Diunduh pada tanggal 09 september 2019 pukul 10.25

http://ilmu-pendidikan.net/. Kriteria pemilihan sumber belajar. Diunduh pada 10 Agustus, 2019 pukul 21.24

https://aldham.wordpress.com. Sumber belajar menurut para ahli. Diunduh 17 Agustus 2019 pukul 16.21.

https://byrugo.wordpress.com. Pemilihan Sumber Belajar. Diunduh, 27 Agustus 2019 pukul 09.17.

http://repository.usu.ac.id/bistream. Hubungan sumber belajar dengan perpustakan. Diunduh, 30 Agustus 2019 pukul 23.11

http://www.wawasanpendidikan.com. Kriteria sumber belajar. Diunduh 12 Agustus 2019, pukul 23.24

http://muhammadden 1.blogspot.co.id. Fungsi dan manfaat sumber belajar. Diunduh 12 Agustus 2019 pukul 23.45

http://rukayani.wordpres.com. Pemanfaatan sumber belajar dalam pendidikan. Di unduh 02 Febuari 2020 pukul 20.30

http://ekacrudgeograf.blogspot.com. Sifat sumber belajar non teks. Di unduh03 febuari 2020 pukul 22.30

http://bahanajarnoncetakanisfadhilah.blogspot.com. Jenisjenis sumber belajar non tek. Di unduh 04 febuari 2020 pukul 23.30.

Kountur, R. 2009. Metode Penelitian. Jakarata: PPM

Kadir, (2019) media sumber belajar \& pembelajaran. RajaGrafindo Persada

Musfiqon, (2015) pengembangan media pembelajaran \& sumber pembelajaran. PT. Prestasi Pustakaraya 